\title{
DISTRIBUTION OF FLOWS IN A CHANNEL NETWORK UNDER STEADY FLOW CONDITIONS
}

\author{
Dariusz Gąsiorowski, Wojciech Artichowicz \\ Faculty of Civil and Environmental Engineering, Gdańsk University of Technology, Gabriela Narutowicza 11/12, 80-233 Gdańsk
}

\section{ABSTRACT}

\section{Aim of the study}

The article presents an algorithm for calculating the distribution of flow in a junction of open channel network under steady flow conditions.

\begin{abstract}
Material and methods
The presented algorithm is based on the continuity equation and a simplified energy equation. To describe the relationship between the depth of water and the flow rate, the Manning's equation was used to express discharge in the main channel, whereas in case of other channels, with hydraulic structures, appropriate equations describing the flow over a weir and through the culverts were used. Substitution of the abovementioned relationships into the continuity equation leads to a non-linear algebraic equation with respect to the water level. The resulting equation can be solved with iterative numerical methods. Calculation example using the proposed algorithm was carried out for the hydraulic system located on the Strzyża stream in Gdańsk.
\end{abstract}

\section{Results and conclusions}

The presented approach can be an alternative to analytical-graphic method and it does not require formulation of the boundary problem for the system of ordinary differential equations describing the gradually varied flow in the open channel network.

Keywords: division of flows, open channel network, steady gradually varied flow, nonlinear equation, flow through weir and culvert

\section{INTRODUCTION}

When a steady gradually varied flow in a network of open channels is considered, often it is necessary to estimate the distribution of flow in its branches. Usually the flow rate $Q$ in one of the channels is known (or the water level $h$ corresponding to this flow rate), whereas the percentage shares of flows in the remaining channels are unknown. Assuming the connection of the three channels presented in Figure 1a, it is necessary to determine the flow rates $Q_{J}$ and $Q_{K}$ in the other two channels - $J$ and $K$, respectively - with the known flow rate of $Q_{I}$.

The above problem is a typical example of the steady gradually varied flow in a channel network. In the classical approach, the problem of this kind can be solved graphically and analytically based on the flow curves of individual channels. A detailed description of this approach is presented by Chow (1959) and French (1985). In order to obtain the solution, one can also formulate the boundary problem for the system of ordinary differential equations (Szymkiewicz, 2000).

凶e-mail:gadar@pg.edu.pl 


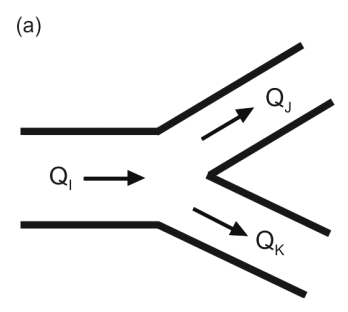

(b)

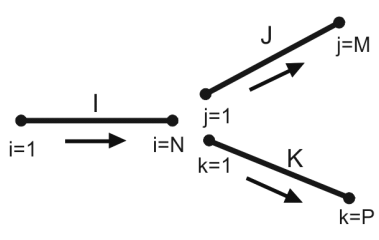

Fig. 1. Three connected channels: general scheme (a), discretisation scheme (b)

Such approach is valid if the flow in the channels is not known. Equations of this type are derived from de Saint Venant system of equations, with the assumption of steady flow conditions. In the case of a single channel, these equations take the following form:

$$
\begin{gathered}
\frac{d}{d x}\left(h+\frac{\alpha \cdot Q^{2}}{2 g \cdot A^{2}}\right)=-S \\
\frac{d Q}{d x}=0
\end{gathered}
$$

where:

$Q \quad-$ flow rate,

$x \quad-$ spatial variable,

$h(x)$ - water level above the assumed datum, $h=$ $z+H$ (see: Fig. 2),

$H(x)$ - water depth,

$z(x)$ - bottom elevation above the assumed datum,

$A(x)$ - wetted cross-sectional area,

$S$ - friction slope,

$\alpha \quad-$ de Saint-Venant coefficient.

The friction slope can be estimated using the transformed Manning equation:

$$
S=\frac{n^{2} \cdot Q^{2}}{A^{2} \cdot R^{4 / 3}}
$$

where $R$ is the hydraulic radius, and $n$ is Manning's roughness coefficient.

The system of differential equations (1-2) describes the changes of the water level $h(x)$ along the channel at a constant flow rate $Q$. That system of equations should be supplemented by two boundary condi- tions, one at the beginning, and one at the end of the channel $L$ (see: Fig. 2):

$$
h(x=0)=h_{0} \text { and } h(x=L)=h_{L}
$$

where $h_{0}$ and $h_{L}$ are the water levels in cross sections $x$ $=0$ and $x=L$, respectively.

The system of differential equations (1-2) written for a single channel can be solved, for example, by applying the implicit trapezoidal rule (Szymkiewicz, 2010; Artichowicz and Gąsiorowski, 2018). As a result of the discretization of equations (1-2) and additionally noticing that $Q_{i}=Q_{i+1}=Q_{I}=$ constant, we obtain the following algebraic equation:

$$
h_{i+1}+\frac{\alpha_{i+1} \cdot Q_{I}^{2}}{2 g \cdot A_{i+1}^{2}}=h_{i}+\frac{\alpha_{i} \cdot Q_{I}^{2}}{2 g \cdot A_{i}^{2}}-\frac{\Delta x}{2}\left(S_{i}+S_{i+1}\right)
$$

where:

$$
\begin{aligned}
& i- \text { cross-section index in the channel, } i=1, \ldots ., \\
& N-1, \\
& N- \text { number of cross-sections, } \\
& I-\text { channel index, } \\
& \Delta x-\text { distance between the sections. }
\end{aligned}
$$

Similar equations can be derived for the remaining channels $J$ and $K$. As a result, a system of $(N-1$ $+M-1+P-1)$ algebraic equations with $(N+1+M$ $+1+P+1)$ unknowns is obtained. There are $(N+$ $M+P)$ unknown values of water levels in particular cross-sections of the channels, and one unknown value of flow rate per channel (Szymkiewicz, 2010). To solve the abovementioned system of equations it is necessary to impose additional conditions at the channel connections, resulting from the conservation of mass principle:

$$
Q_{I}=Q_{J}+Q_{K}
$$

and from the energy conservation principle:

$$
h_{i}+\frac{\alpha \cdot Q_{I}^{2}}{2 g \cdot A_{i}^{2}}=h_{j}+\frac{\alpha \cdot Q_{J}^{2}}{2 g \cdot A_{j}^{2}}=h_{k}+\frac{\alpha \cdot Q_{K}^{2}}{2 g \cdot A_{k}^{2}}
$$

where:

$$
\begin{aligned}
I, J, K- & \text { channel designations (see: Fig. } 1 \mathrm{a}), \\
i, j, k- & \text { designation of nodes at the channels' con- } \\
& \text { nection, } i=N, j=1, k=1 \text { (see: Fig. } 1 \mathrm{~b}) .
\end{aligned}
$$




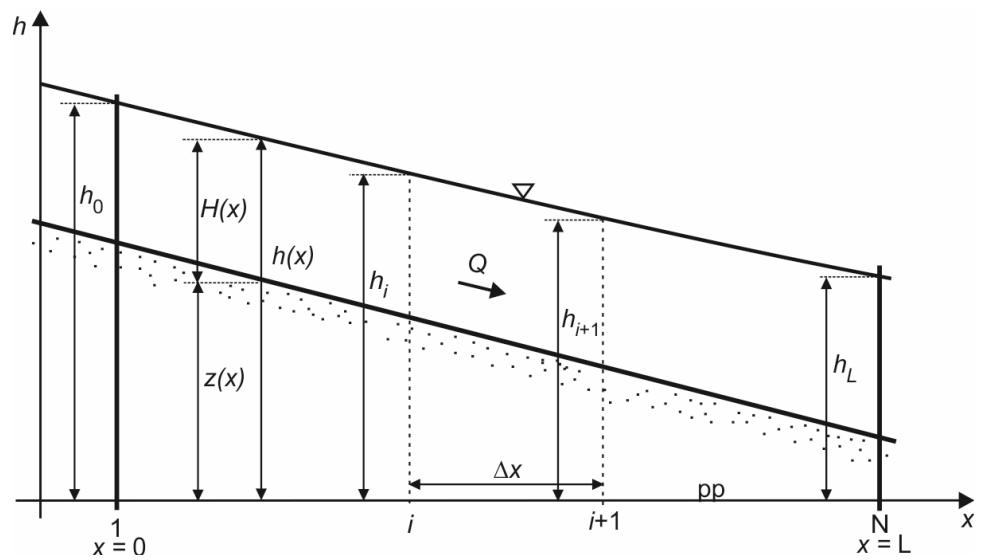

Fig. 2. Calculation scheme of longitudinal profile for the system of ordinary differential equations describing steady gradually varied flow

Algebraic equations (5) written for individual channels constitute a global system of nonlinear equations. This system, supplemented with the known boundary conditions $(4 \mathrm{a}, \mathrm{b})$ and with the compliance conditions $(6,7)$, can be solved using the Picard method (Szymkiewicz, 2010). As a result, we obtain the flow rates in individual channels $Q_{N}, Q_{J}, Q_{K}$ and the water level profile $-h(x)$ - along the channels.

In the above-mentioned formulation of flow distribution issues, the boundary conditions for obtaining the correct solution must be imposed. In other words, the water level values at the end of channel $h_{i=1}, h_{j=N}$, $h_{k=N}$ are required (see: Fig. 1b). When these values are unknown, this requirement may constitute a significant limitation. Most often, the end section is an ordinary channel cross-section, and then the boundary condition can be determined on the basis of the relationship between the flow rate and the water elevation in the form of the flow curve $Q=Q(h)$ or in the form of the Manning equation. On the other hand, if the water in the channels flows through hydraulic structures, then the known formulas describing the relationship between the flow rate and the hydraulic head of a given structure can be used.

\section{FLOW DISTRIBUTION CALCULATED ON THE BASIS OF SOLVING THE NONLINEAR MASS BALANCE EQUATION}

Due to the approximation of the system of ordinary differential equations, a system of non-linear algebraic equations arises (Eq. (5)) which has to be solved.
Besides the application of an appropriate method to solve such a system of equations, the convergence of the iterative process itself may become an issue. Another problem complicating the solution is the variable number of roots of the resulting algebraic equations (5) (Artichowicz and Szymkiewicz, 2014). Therefore, in order to avoid the aforementioned problem, alternative methods can be proposed which result from appropriate simplifications. If the scope of interest is only the information regarding the percentage distribution of flows, this issue can be significantly simplified by omitting information related to the water level profile along the channels. Then, the solution of the flow distribution problem can be based only on the conditions (6-7). In this approach, the mass balance equation (6) is adopted in an unchanged form, while in the energy equation (7) for small differences in velocity, only the compliance of water levels can be assumed:

$$
h_{i=N}=h_{j=1}=h_{k=1}=h
$$

Additionally, using appropriate relationships between the water level elevation $h$, and the flow rate in individual channels $Q=Q(h)$ (for instance, the Manning equation, or the flow formula through weir or culvert), the mass balance equation for the open channel network node can be ultimately rewritten in the following form:

$$
Q_{I}(h)-Q_{J}(h)-Q_{K}(h)=0
$$

In the presence of hydraulic structures, it is assumed that these structures are located at a sufficient- 
ly close distance from the network junction, so that the water level in the junction simultaneously corresponds to the level determining the hydraulic head of the structure. The mass balance equation obtained in this way is a nonlinear equation with one unknown, that is, the water level $h$. This equation can be solved by any method used for solving algebraic nonlinear equations, for instance Newton's, Picard's, false position, or simple fixed point iteration method. Due to this approach, the flow distribution problem is reduced to solving only one algebraic nonlinear equation instead of a system of equations.

\section{APPLICATION EXAMPLE}

Flow distribution calculations were performed for the river network junction near the Srebrniki reservoir located on the Strzyża stream in Gdańsk (see: Fig. 3). The junction consists of a section of the main channel with a trapezoidal cross section (see: Fig. 4a), connected to two other channels. One of the two channels transports water to the reservoir through a rectangular culvert (see: Fig. 4b), while the other one is the diversion channel of this reservoir, including two circular culverts over which the trapezoidal weir is located (see: Fig. 4c). Therefore, the flow in the main channel $Q_{g}$ is distributed to flow through the culvert towards the reservoir $Q_{p}$ and the flow in the diversion channel $Q_{o}$ (see:
Fig. 3a). The flow in the diversion channel depends on its current water level. Flow can take place through the circular culverts with flow rate $Q_{k}$ only or additionally through the trapezoidal weir with flow rate $Q_{t}$. Taking into account these hydraulic schemes, the non-linear mass balance equation with respect to the depth $H$ written for the analysed junction takes the following form:

$$
\begin{aligned}
& Q_{g}-Q_{p}(H)-\left(Q_{k}(H)+Q_{t}(H)\right)=0 \\
& \quad \text { or } \\
& Q_{g}-Q_{p}(H)-Q_{o}(H)=0
\end{aligned}
$$

In the considered task, it was assumed that in the main channel a subcritical flow occurs, i.e. the depth $H$ is greater than the critical depth $\left(H>H_{k r}\right)$. In addition, because the capacity of the diversion channel, as well as the channel transporting water to the reservoir is smaller than in the main channel at normal depth $H_{n}$, the water in the cross-section of the computational node will increase to the depth of $H\left(H>H_{n}\right)$. As a result, on the analysed section in the main channel, a backwater profile is created. This situation is schematically illustrated in Figure 3b.

In the main inflow channel and the diversion channel (see: Fig. 4a, c), the relation between the flow rate and water depth has been determined using the Manning equation for the trapezoidal cross-section: (a)

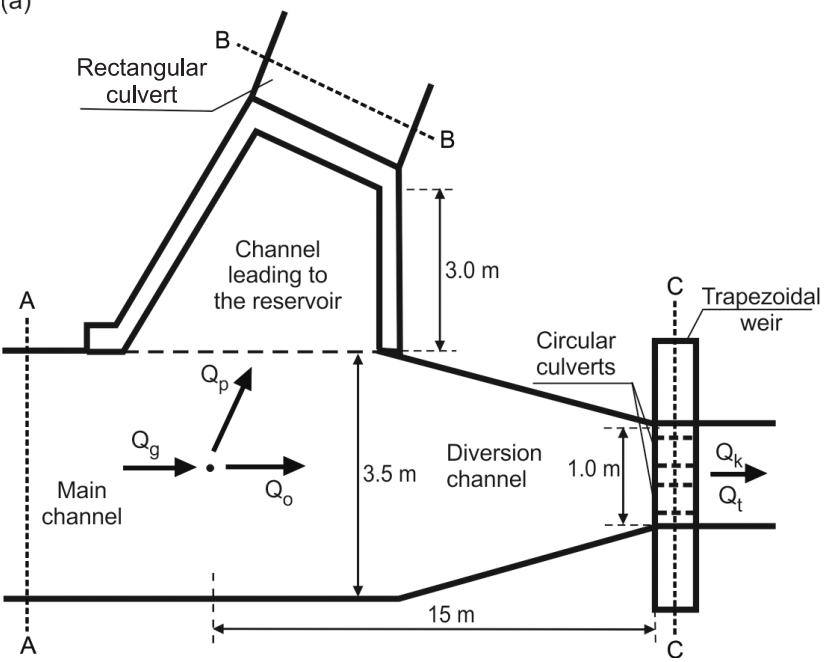

(b)

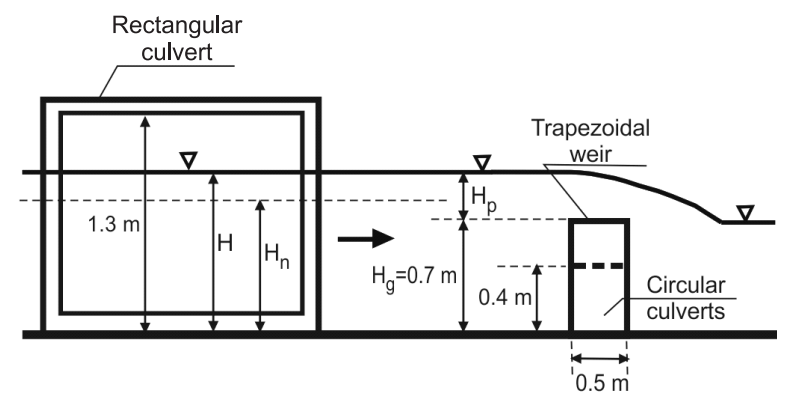

Fig. 3. "Srebrniki" hydraulic node: plan view (a), longitudinal section (b). 


$$
Q_{g}=\frac{1}{n} \frac{\left(b \cdot H+m \cdot H^{2}\right)^{5 / 3}}{\left(b+2 H \sqrt{1+m^{2}}\right)^{2 / 3}} s^{1 / 2}
$$

where:

$$
\begin{aligned}
& b \text { - width of the channel at the bottom level, } \\
& s \text { - channel bed slope, } \\
& m \text { - bank slope parameter. }
\end{aligned}
$$

In the case of the hydraulic structures, the appropriate formula was adopted for a given culvert or weir depending on the current water level in the channel. The water level in turn determines the corresponding hydraulic condition, in which the structures operate. The culvert may operate with a free-surface flow or a pressurized flow. The first type of flow occurs when the following conditions for non-submerged inlet and outlet are fulfilled (Bodhaine, 1976; French, 1985):

$$
H / D<1.5, \quad H_{d}<D
$$

where:

$H$ - water depth above the inlet bottom,

$D$ - height or diameter of the culvert,

$H_{d}$ - water depth above the bottom of the outlet.

In addition, for the flow with a free surface, we need to distinguish between the conditions of subcritical flow and those of supercritical flow (see: Fig. 5a, b). In this case, the formulas for calculating the discharge take the following forms, respectively - for subcritical flow $\left(s<s_{k r}\right)$ (French, 1985; Szpakowski, 2015):

$$
Q=\mu_{N} \cdot A_{d} \cdot \sqrt{2 g\left(\Delta H-H_{L}\right)}
$$

and for supercritical flow $\left(s>s_{k r}\right)$ :

$$
Q=\mu_{N} \cdot A_{k r} \sqrt{2 g\left(H-H_{k r}\right)}
$$

where:

$$
\begin{aligned}
& s \quad-\text { culvert bed slope, } \\
& s_{k r} \text { - critical slope, } \\
& \mu_{N} \quad-\text { discharge coefficient (non-submerged in- }
\end{aligned}
$$

Additionally, the flow with a free surface, submerged inlet and with a non-submerged outlet (see: Fig. 5c) should be taken into consideration. For this case, the following formula can be used:

$$
Q=\mu_{z} \cdot A_{0} \cdot \sqrt{2 g \cdot H}
$$

where:

$\mu_{z}$ - discharge coefficient (submerged inlet),

$A_{0}$ - cross-sectional area at the culvert inlet corresponding to the area completely filled with water.

In order to determine the flow rate in the culvert operating in pressurized flow conditions (see: Fig. 5d), the formula (13) can be used, with the only difference being that the cross-sectional area $A_{d}$ will correspond (a)

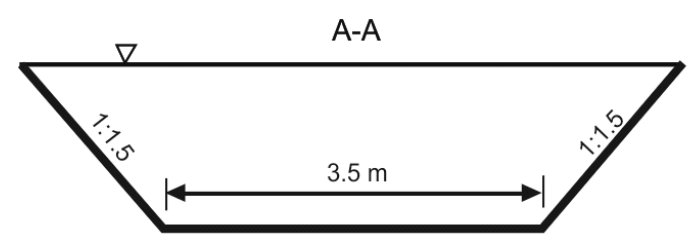

(b)

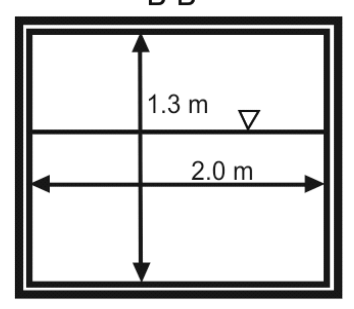

(c)

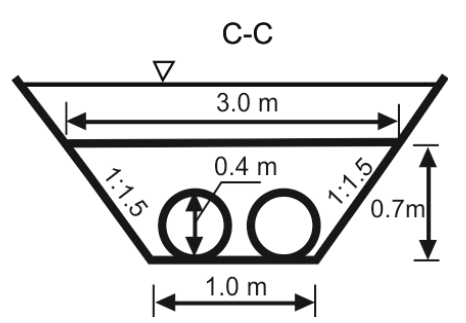

Fig. 4. Cross sections of: the main channel (a), rectangular culvert (b), trapezoidal weir and circular culverts in the diversion flow channel (c) 
to the area of the culvert cross-section completely filled with water, i.e. $A_{d}=A_{0}$.

The values of the discharge coefficients $\mu$ depend mainly on the geometry of the culvert, the type of inlet construction and the depth of water $H$ before the inlet (French, 1985; Kubrak and Kubrak, 2004).

The trapezoidal weir, located above the circular culverts, can operate as a non-submerged or submerged weir structure depending on the hydraulic conditions (see: Fig. 6). In non-submerged conditions, the discharge of the weir can be determined on the basis of the following formula (Sawicki, 2009):

$$
Q=\frac{2}{15} \mu_{P T} \sqrt{2 g}\left(5 B \cdot H_{p}^{3 / 2}+4 \operatorname{tg} \alpha \cdot H_{p}^{5 / 2}\right)
$$

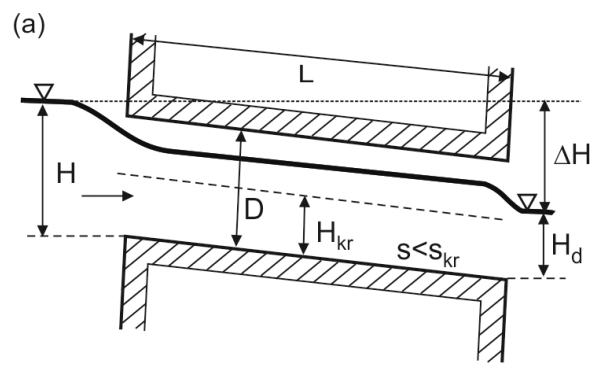

(c)

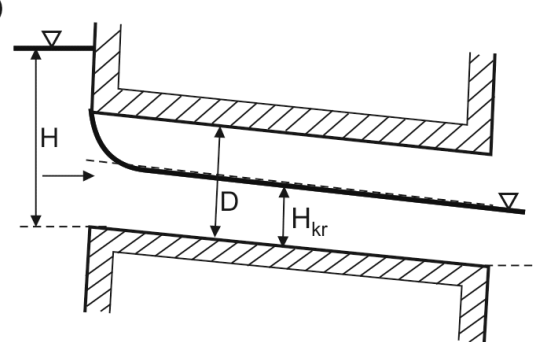

where:

$H_{p}-$ hydraulic head of the weir, $H_{\mathrm{p}}=H-H_{g}$,

$H_{g}$ - height of the weir,

$B^{g}$ - width of the weir at the threshold level,

$\mu_{P T}$ - discharge coefficient,

$\alpha-$ angle of inclination of the weir edge to the vertical.

The weir is considered to be submerged when the following conditions are fulfilled (see: Fig. 6a):

$$
H_{o}>H_{g} \text { and } \Delta H / H_{g}<0.7
$$

where:

$H_{o}$ - water depth after the weir,

$\Delta H$ - difference of water levels before and after the weir, $\Delta H=H-H_{o}$.

(b)

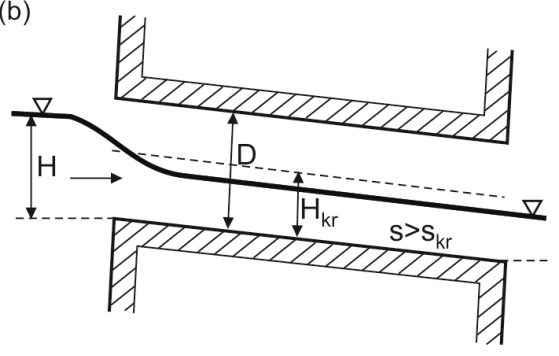

(d)

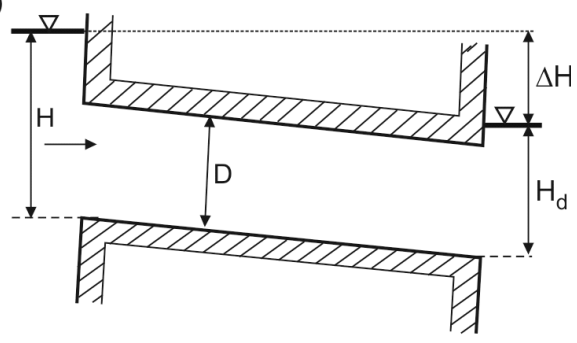

Fig. 5. Hydraulic schemes of the culvert operation during the flow: with free surface, non-submerged inlet (subcritical flow) (a), with free surface, non-submerged inlet (supercritical flow) (b), with free surface, submerged inlet (c), pressurized flow (d)

(a)

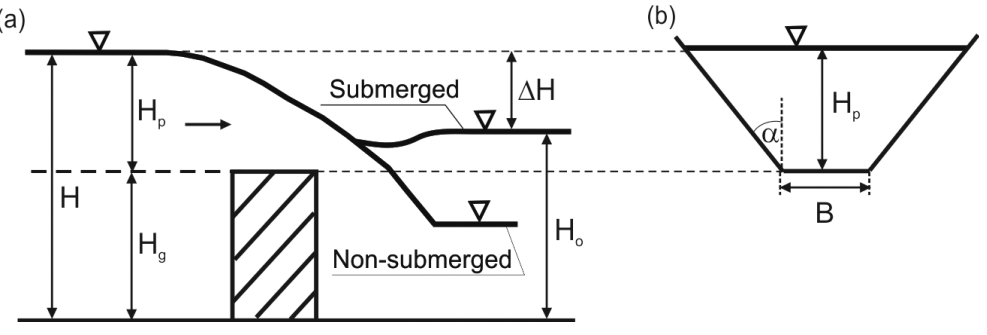

Fig. 6. Hydraulic schemes of the weir (a), cross-section of the trapezoidal weir (b) 
Then the discharge of the weir can be estimated according to the following expression:

$$
Q_{z}=\sigma \cdot Q
$$

where $Q$ is the discharge determined for a non-submerged weir, while $\sigma$ is a submergence factor of the weir, the value of which can be computed according to the following formula (Kubrak and Kubrak, 2004):

$$
\sigma=1.05\left(1+0.2 \frac{\left(H_{o}-H_{g}\right)}{H_{g}}\right)\left(\frac{\Delta H}{H_{p}}\right)^{1 / 3}
$$

\section{COMPUTATIONAL ALGORITHM}

The presented formulas make it possible to estimate the discharges of individual structures in the mass balance equation (10a). The non-linear equation obtained in this way, was solved with respect to water depth $H$ using the false position method. While solving the equation, first the initial approximation of the normal depth $H^{0}$ in the main channel has to be determined for the given flow rate $Q_{g}$ (see: Fig. 7). This depth is determined on the basis of the Manning equation, which is equivalent to solving the non-linear equation (11). The determined value of the depth $H^{k}=H^{0}$ (where $k$ denotes the iteration index) is at the same time the hydraulic head of the culverts that allows estimating the discharge to the reservoir through the rectangular culvert $Q_{p}\left(H^{k}\right)$. Using the mass balance equation (10b), the flow rate in the diversion channel $Q_{o}=Q_{g}-Q_{p}$ is also computed. The character of the flow in the diversion channel near the circular culverts and the trapezoidal weir depends on the hydraulic conditions before and after the given structure. In the case of a culvert, this may be flow with a free surface or the pressurized flow, whereas the weir may work either as non-submerged or submerged.

Therefore, in order to identify the proper operation of the hydraulic system, it is also necessary to determine depth $H_{o}^{k}$ in the diversion channel after the structures using the Manning equation. Based on the knowledge of the depth approximations $H^{k}$ and $H_{o}^{k}$ in the given iteration $k$, it is possible to determine - by adopting the appropriate calculation scheme - the values of flow through the circular culverts $Q_{k}\left(H^{k}, H_{o}^{k}\right)$ and through the trapezoidal weir $Q_{t}\left(H^{k}, H_{o}^{k}\right)$. The iterative process of approximating the depth $H$ is carried out until the mass balance equation (10a) is fulfilled with the given required accuracy, in other words, the calculations are completed when the following convergence criterion is fulfilled:

$$
\left|H^{(k+1)}-H^{(k)}\right| \leq \varepsilon
$$

where:

$\varepsilon$ - required accuracy, the value of $\varepsilon=0.0001 \mathrm{~m}$ was adopted in the study.

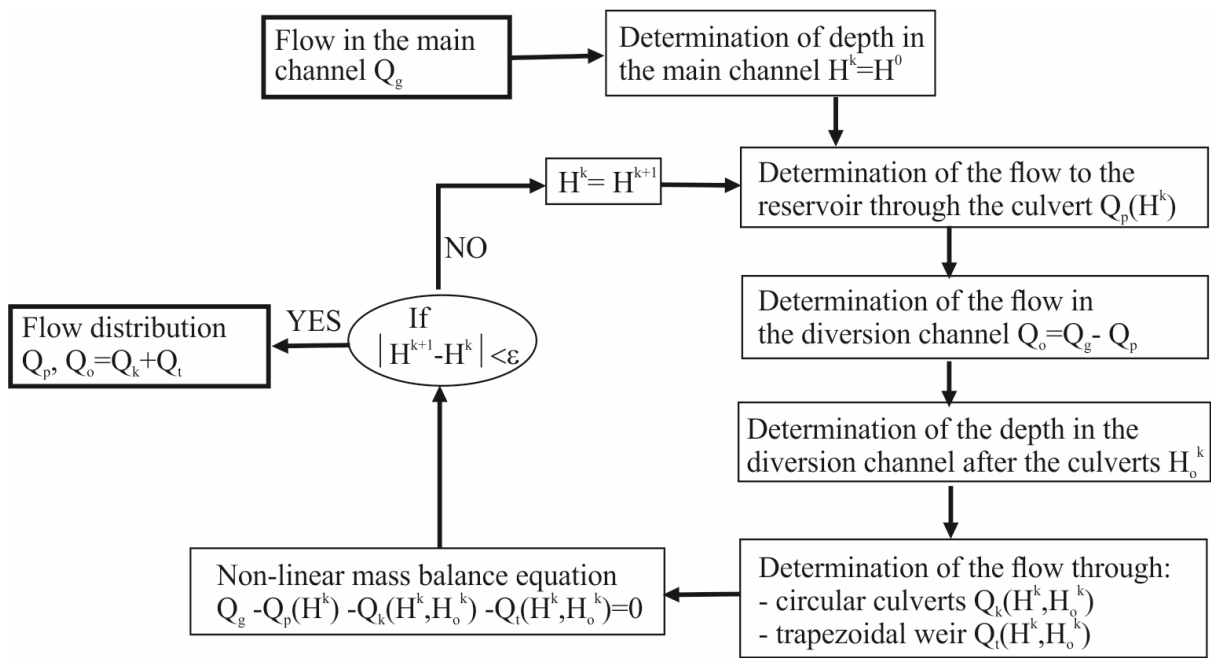

Fig. 7. Computational algorithm for flow distribution in the analysed hydraulic node 


\section{EXAMPLE OF COMPUTATIONS}

In the analysed hydraulic system, the channels have a trapezoidal shape in the cross-section, with a bank slope of $m=1.5$ and a bottom slope of $i=0.5 \%$. In turn, the widths at the bottom of the main channel and the diversion channel are assumed to be equal to $b_{g}=3.5 \mathrm{~m}$ and $b_{o}=1.0 \mathrm{~m}$, respectively (see: Fig. $4 \mathrm{a}$, c). In these channels, a constant Manning coefficient value $n=0.02 \mathrm{~m}^{-1 / 3} \mathrm{~s}$ was assumed. Due to the significant bottom slope in the rectangular culvert $(s=3 \%)$, it was assumed that this culvert would operate only in the supercritical flow. In such case the possibility of submerging the inlet does not occur and the discharge of the culvert $Q_{p}$ can be determined by means of the formula (14). In the case of circular culverts and trapezoidal weir, it was assumed that they could operate in the submerged and non-submerged flow conditions. The discharge $Q_{k}$ in this case is determined by the equations (13-15), whereas the weir discharge $Q_{t}$ is determined by the equations (16) and (18). In order to simplify the calculations, the hydraulic losses $\left(H_{L}=0\right)$ in circular culverts were omitted. Also fixed values of discharge coefficients were assumed for culvert and weir operating in the given hydraulic condi- tions. The assumed values of geometrical and hydraulic parameters of individual structures are presented in Table 1.

The flow distribution calculations were performed for the assumed flow rate in the main channel $Q_{g}$. The highest value of the flow rate corresponded to the maximum flow with the probability of exceedance $p=10 \%$, that is, $Q_{g}=Q_{10 \%}=6 \mathrm{~m}^{3} \cdot \mathrm{s}^{-1}$. The calculations were carried out for the existing system as well as for a hypothetical system without the circular culverts and trapezoidal weir in the diversion channel. The results of the flow distribution calculations are presented in the form of the characteristics showing the relation between the flow rate and the depth $Q=f(H)$ (see: Fig. 8a, 9a) as well as the percentage share of individual flows with regard to the flow $Q_{g}$ in the main channel (see: Fig. 8b, 9b). This relative share was estimated according to the following relationship:

$$
\Delta Q=\frac{Q_{i}}{Q_{g}} 100 \%
$$

where $Q_{i}$ denotes flow through the appropriate channel or structure $\left(Q_{o}, Q_{p}, Q_{k}\right.$ or $\left.Q_{t}\right)$.

Table 1. Assumed values of the parameters of structures operating in the analysed hydraulic conditions

\begin{tabular}{|c|c|c|c|c|c|}
\hline Device & & aulic scheme & Criterion & $\begin{array}{c}\text { Geometrical } \\
\text { parameters }\end{array}$ & $\begin{array}{l}\text { Discharge } \\
\text { coefficients }\end{array}$ \\
\hline \multirow{4}{*}{$\begin{array}{l}\text { Circular } \\
\text { culvert }\end{array}$} & \multirow{3}{*}{$\begin{array}{l}\text { Flow with a free } \\
\text { surface }\end{array}$} & $\begin{array}{l}\text { Non-submerged inlet and } \\
\text { outlet, subcritical flow }\end{array}$ & $H / D<1.5, H_{d}<D, s<s_{k r}$ & \multirow{4}{*}{$D=0.4 \mathrm{~m}$} & 0.85 \\
\hline & & $\begin{array}{l}\text { Non-submerged inlet and } \\
\text { outlet, supercritical flow }\end{array}$ & $H / D<1.5, H_{d}<D, s>s_{k r}$ & & 0.90 \\
\hline & & $\begin{array}{l}\text { Submerged inlet, } \\
\text { non-submerged outlet }\end{array}$ & $H / D>1.5, H_{d}<D$ & & 0.50 \\
\hline & $\begin{array}{l}\text { Flow under } \\
\text { pressure }\end{array}$ & $\begin{array}{l}\text { Submerged inlet and } \\
\text { outlet }\end{array}$ & $H / D>1.0, H_{d}>D$ & & 0.60 \\
\hline $\begin{array}{l}\text { Rectangular } \\
\text { culvert }\end{array}$ & $\begin{array}{l}\text { Flow with a free } \\
\text { surface }\end{array}$ & $\begin{array}{l}\text { Non-submerged inlet and } \\
\text { outlet, supercritical flow }\end{array}$ & $H / D<1.5, H_{d}<D, s>s_{k r}$ & $\begin{aligned} D & =1.3 \mathrm{~m} \\
B & =2.0 \mathrm{~m}\end{aligned}$ & 0.90 \\
\hline \multirow{2}{*}{$\begin{array}{l}\text { Trapezoidal } \\
\text { weir }\end{array}$} & Non-submerged & & - & \multirow{2}{*}{$\begin{array}{c}B=3.0 \mathrm{~m} \\
\operatorname{tg} \alpha=1.5 \\
H_{g}=0.7 \mathrm{~m}\end{array}$} & 0.60 \\
\hline & Submerged & & $H_{o}>H_{g}, \Delta H / H_{g}<0.7$ & & Formula (19) \\
\hline
\end{tabular}


When analysing the graph in Figure $8 \mathrm{~b}$, it can be observed that in the existing system for various depths $H$, there are different distributions of the flow. This relationship has a nonlinear character and results from the fact that in individual channels the structures can operate in different hydraulic conditions. For the depth range of $0.1-0.5 \mathrm{~m}$, a nearly constant trend in flow distribution is obtained (see: Fig. 8b), where the flow to the reservoir through the culvert $Q_{p}$ is about $70 \%$ of the flow in the main channel $Q_{g}$, whereas the flow to the diversion channel $Q_{o}$ is $30 \%$ of that flow. In this depth range, the flow in the diversion channel takes place only through circular culverts, i.e. $Q_{o}=Q_{k}$. For depths above $0.6 \mathrm{~m}$, the condition for non-submerged inlet (Eq. (12a)) is not fulfilled, which causes a change in the hydraulic conditions of the culverts' operation, and thus affects the value of the flow rate. Above the depth of $0.7 \mathrm{~m}$, there is a gradual increase in the flow $Q_{o}$ in the diversion channel, which is accompanied with the percent decreasing discharge $Q_{p}$ to the reservoir. This results from the fact that the depths $H>0.7 \mathrm{~m}$ correspond to the position of the water level above the threshold of the trapezoidal weir (see: Fig. 3b and Fig. 6a), which in turn causes the inclusion of that trapezoidal weir in the operation with discharge $Q_{t}$. Therefore, the flow in the diversion channel takes place both through the circular culverts and through the weir, thus $Q_{o}=Q_{k}+$ $Q_{t}$. In addition, for the appropriate value of the depth $H_{o}$ after the culverts, inlets of the culverts may become submerged, which forces the pressurized flow. A further increase in the depth of $H_{o}$ also causes submerging of the weir.

The situation is different in the flow distribution when the lack of culverts and weir in the diversion channel is assumed (see: Fig. 9). In this case, the increase in value of depth causes a gradual increase in the percentage share (from $40 \%$ to $65 \%$ ) of the flow $Q_{o}$ in the diversion channel, while at the same time the flow $Q_{p}$ to the reservoir is reduced from $60 \%$ to almost $35 \%$. Significantly lower values of inflow to the reservoir, in comparison to the existing system shown in Figure 8, are obviously due to an absence of backwater effect in the diversion channel. (a)

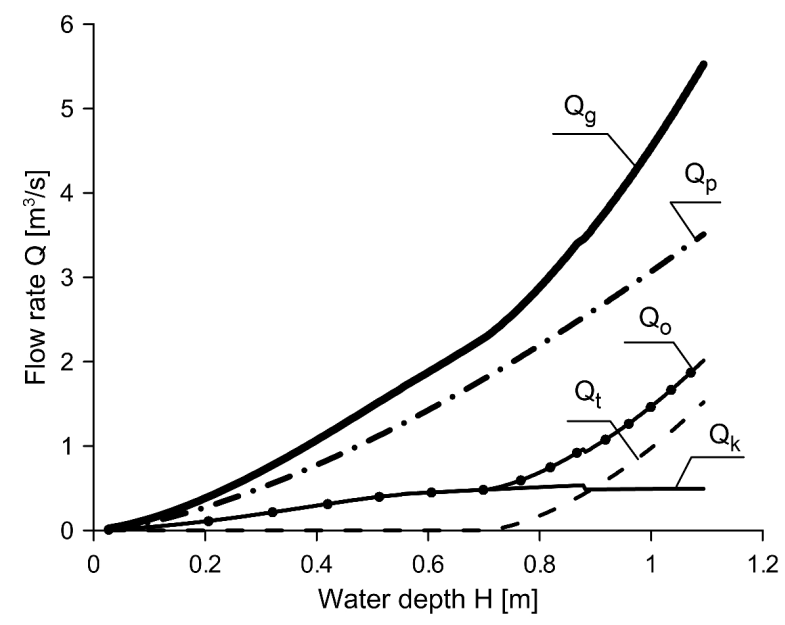

(b)

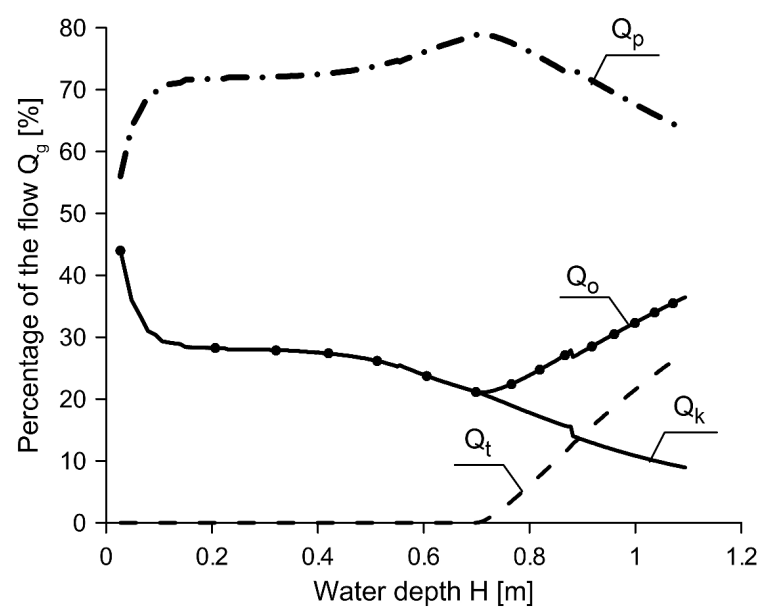

Fig. 8. Results of flow distribution computations for the existing system: characteristics of $Q=f(H)$ for individual channels and structures (a), percentage share of the flow $Q_{g}(\mathrm{~b})$ 
(a)

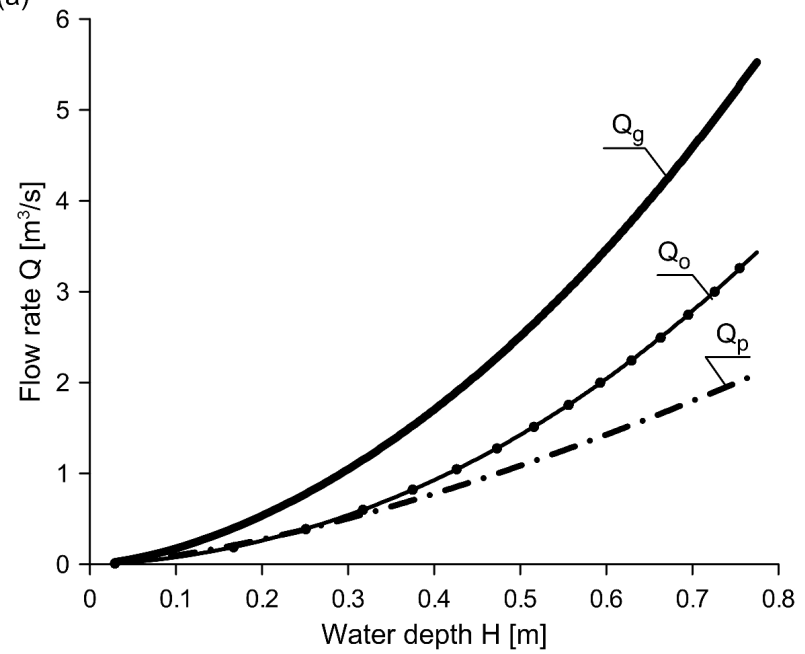

(b)

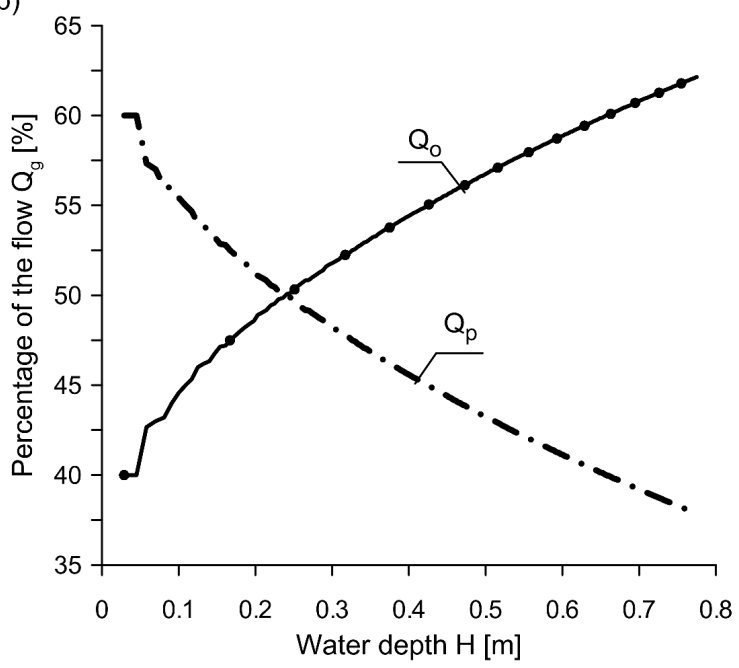

Fig. 9. Results of flow distribution computations without the hydraulic structures in diversion channel: characteristics of $Q=f(H)$ for individual channels (a), percentage share of the flow $Q_{g}$ (b)

\section{CONCLUSIONS}

The article presents a computational algorithm for determining the flow distribution in the junction of open channels network under steady gradually varied flow conditions. The algorithm is based on the adequate conditions at the junction of the channels, resulting from the continuity equation and a simplified energy equation, in which only the conformity of water levels has been taken into consideration. Additionally, using the relationships between the water level and the flow rate in individual channels including hydraulic structures, the simplified mass balance equation was derived. For this reason, the obtained mass balance equation is a non-linear one with regard to the water depth. In the present work, the false point method was used in order to solve this equation. Consequently, due to this approach the flow distribution problem was reduced to solving only one algebraic non-linear equation instead of a system of equations. Therefore, the presented flow distribution algorithm can offer an alternative to the analytical-graphic method or a method based on the solution of the boundary problem for the system of ordinary differential equations describing the steady gradually varied flow in the open channel network.
Sample computations using the proposed algorithm were carried out for the hydraulic system of the network of channels located on the Strzyża stream in Gdańsk. Flow distribution calculations were performed for different values of the determined flow rate in the main channel - for the existing system, as well as for the hypothetical system without the hydraulic structures in the diversion channel.

\section{REFERENCES}

Artichowicz, W., Gąsiorowski, D. (2018). Numerical Analysis of Steady Gradually Varied Flow in Open Channel Networks with Hydraulic Structures. In: M. Kalinowska, M. Mrokowska, P. Rowiński, Free Surface Flows and Transport Processes, Springer International Publishing, 127-142.

Artichowicz, W., Szymkiewicz, R. (2014). Computational issues of solving the 1D steady gradually varied flow equation. Journal of Hydrology and Hydromechanics, 62(3), 226-233.

Bodhaine, G. L. (1976), Measurement of Peak Discharge At Culverts by Indirect Methods. Techniques of Water Resources Investigation of the United States Geological Survey. U.S. Geological Survey, Washington.

Chow, V. T. (1959). Open channel hydraulics. McGraw-Hill Book Company. 
French, R. H. (1985). Open -channel hydraulics. New York: MacGraw-Hill.

Kubrak, E., Kubrak, J. (2004). Hydraulika techniczna przykłady obliczeń. Warszawa: Wydawnictwo SGGW.

Sawicki, J.M. (2009). Mechanika przepływów. Gdańsk: Wydawnictwo Politechniki Gdańskiej.

Szpakowski, W. (2015). Przepustowość hydrauliczna przepustu kołowego w warunkach niezatopionego wlotu. Acta Sci. Pol. Formatio Circumiectus, 14 (2) 2015, 195-207.

Szymkiewicz, R. (2000). Matematyczne modelowanie przepływów w rzekach i kanałach. Warszawa: PWN.

Szymkiewicz., R., (2010). Numerical modeling in open channel hydraulics. Water Science and Technology Library, New York: Springer.

\section{ROZDZIAŁ PRZEPŁYWÓW W SIECI KANAŁÓW W WARUNKACH RUCHU USTALONEGO}

\section{ABSTRAKT}

\section{Cel pracy}

W artykule przedstawiono uproszczony algorytm obliczeniowy służący do oszacowania rozdziału przepływów w sieci kanałów w warunkach przepływu ustalonego.

\section{Materiał i metody}

Algorytm obliczeniowy opiera się na warunkach zgodności w połączeniu kanałów wynikających z równania zachowania masy oraz uproszczonego równania energii, w którym przyjęto tylko zgodność poziomów wody. Wykorzystując dodatkowo związki pomiędzy rzędną zwierciadła wody, a natężeniem przepływu w poszczególnych kanałach oraz urządzeniach występujących w tych kanałach wyprowadzono odpowiednie równanie. Otrzymane w ten sposób równanie bilansu masy jest równaniem nieliniowym względem tylko głębokości wody. W pracy do rozwiązania tego równania wykorzystano metodę siecznych. Przykładowe obliczenia z wykorzystaniem zaproponowanego algorytmu przeprowadzono dla układu hydraulicznego znajdującego się na potoku Strzyża w Gdańsku.

\section{Wyniki i wnioski}

Zaproponowany algorytm rozdziału przepływów może stanowić alternatywę do metody analityczno-graficznej lub metody opartej na rozwiązaniu zagadnienia brzegowego dla układu równań różniczkowych zwyczajnych opisujących przepływ ustalony niejednostajny w sieci kanałów.

Słowa kluczowe: rozdział przepływów, sieć kanałów otwartych, ruch ustalony niejednostajny, przepływ przez przelew oraz przepust, równanie nieliniowe 
